УДК 342.9

DOI: https://doi.org/10.54929/pmtl-issue1-2021-01

\title{
CONTEXTUAL INTERPRETATION OF CONCEPTS AND CATEGORIES ADMINISTRATIVE LITIGATION: BASIC TECHNIQUES AND RULES
}

\author{
КОНТЕКСТУАЛЬНЕ ТЛУМАЧЕННЯ ПОНЯТЬ ТА КАТЕГОРІЙ \\ АДМІНІСТРАТИВНОГО СУДОЧИНСТВА: ОСНОВНІ ПРИЙОМИ \\ ТА ПРАВИЛА
}

\author{
Oleh Bilous \\ doctor of law, \\ Judge, Supreme Court of Ukraine
}

Білоус О. В.

доктор юридичних наук, суддя, Верховний Суд України ORCID: 0000-0002-9755-6800

In the article, on the basis of the generalized analysis of scientific, journalistic and normative sources, the methods and rules of contextual interpretation of the concepts and categories of administrative justice are defined. It is noted that contextual interpretation of the concepts and categories of administrative justice is a set of techniques and rules, based on which contextual analysis is used, by which the content of the relevant concept or category of administrative process is established based on socio-cultural, law-enforcement and / or situational contexts of their meaning. It is noted that contextual interpretation is considered inseparably linked to philological interpretation, since the contextual way of interpretation is a kind of subtype of philological interpretation, and its main method - contextual analysis - is an integral part of linguistic analysis. On the basis of the above, the basic rules and techniques of contextual interpretation of the concepts and categories of administrative justice are formulated, in particular: reception of harmonious reading - the content of concepts or categories that relate to one institution of administrative process or process as a whole should be interpreted in such a way as to make them compatible and not contradictory; related words matter to each other; concepts are given the meaning that is associated with them in a given circle of persons; titles and headings are permissible indicators of the meaning of the relevant concept as defined in the CAS; if the legal act does not define in one way or another the meaning of legal terms, they should be given the meaning in which they are used in the acts of interpretation or in the legal doctrine, etc.; applying the techniques of situational contextual analysis to the interpretation of valuation concepts.. Key words: administrative judiciary, analysis, concepts, categories, philological interpretation, context.

У cтатmі, на підставі узагальненого аналізу наукових, публіцистичних та нормативних джерел, визначено прийоми та правила контекстуального тлумачення понять та категорій адміністративного судочинства. Відзначено, що контекстуальне тлумачення понять і категорій адміністративного судочинства - це сукупність прийомів і правил, в основі застосування яких знаходиться контекстуальний аналіз, за допомогою якого встановлюється зміст відповідного поняття або категорії адміністративного процесу виходячи з соціокультурних, правозастосовних та / або ситуаційних контекстів їх значення.Зауважено, що контекстуальне тлумачення розалядається у нерозривному зв'язку із фрілологічним тлумаченням, оскільки контекстуальний спосіб інтерпретації є своєрідним підвидом фрілологічного тлумачення, а його основний метод - контекстуальний аналіз - $\epsilon$ складовою частиною лінгвістичного аналізу. Узагальнений огляд доктринальних джерел з теорії тлумачення правових норм та їі методів показав, що цей вид тлумачення залишається майже недослідженим вітчизняною юридичною наукою, що зумовлює підвищений інтерес до його правової природи та правил і методів юридичної науки. На підставі зазначеного, сформульовано основні правила та прийоми контекстуального тлумачення понять і категорій адміністративного судочинства, зокрема: прийом гармонійного читання - зміст понять або категорій, що стосуються одного інституту адміністративного процесу або процесу в цілому повинен тлумачитися таким чином, щоб зробити їх сумісними, а не такими, що суперечать один одному; пов'язані слова ма- 
ють значення один для одного; поняттям надається те значення, яке з ними пов'язується в даному колі осіб; назви та заголовки є допустимими показниками значення відповідного поняття, сформульованого у КАC; якщо в законодавчому акті не визначено тим чи іншим способом значення юридичних термінів, їм слід надавати те значення, в якому вони вживаються в актах тлумачення або в юридичній доктрині тощо; застосування прийомів ситуаційного контекстуального аналізу до тлумачення оціночних понять. Ключові слова: адміністративне судочинство, аналіз, поняття, категорії, фрілологічне тлумачення, контекст.

В статье, на основании обобщенного анализа научных, публицистических и нормативных источников, определены приемы и правила контекстуального толкования понятий и категорий административного судопроизводства. Отмечено, что контекстуальное толкование понятий и категорий административного судопроизводства - это совокупность приемов и правил, в основе применения которых находится контекстуальный анализ, с помощью которого устанавливается содержание соответствующего понятия или категории административного процесса исходя из социокультурных, правоприменительных и / или ситуационных контекстов их значення.Зауважено , что контекстуальное толкование рассматривается в неразрывной связи с филологическим толкованием, поскольку контекстуальный способ интерпретации является своеобразным подвидом филологического толкования, а его основной метод - контекстуальный анализ - является составной частью лингвистического анализа. На основании указанного, сфрормулированы основные правила и приемы контекстуального толкования понятий и категорий административного судопроизводства, в частности: прием гармоничного чтения - содержание понятий или категорий, касающихся одного института административного процесса или процесса в целом должен толковаться таким образом, чтобы сделать их совместимыми, а не противоречащими друг другу; связанные слова имеют значение друг для друга; понятием имеет то значение, которое с ними связывается в данном кругу лиц; названия и заголовки являются допустимыми показателями значение соответствующего понятия, сформулированного в КАС; если в законодательном акте не определено тем или иным способом значение юридических терминов, им следует предоставлять то значение, в котором они употребляются в актах толкования или в юридической доктрине и тому подобное; применение приемов ситуационного контекстуального анализа к толкованию оценочных понятий.. Ключевые слова: административное судопроизводство, анализ, понятия, категории, фрилологическое толкование, контекст.

\section{Statement of the problem in general and its connection with important scientific or practical}

tasks. Analysis of law enforcement practice on the interpretation of concepts and categories of administrative proceedings revealed that among the traditional means and methods of interpretation, the set of which is embodied in certain ways of interpretation (philological, historical, political, systemic) in clarifying and clarifying terminological constructions of administrative process the court also applies the so-called contextual interpretation. At the same time, a generalized review of doctrinal sources on the theory of interpretation of legal norms and its methods showed that this type of interpretation remains almost unexplored by domestic legal science, which leads to increased interest in its legal nature and rules and methods of its application.

An analysis of recent research and publications in which the solution to this problem has been initiated and on which the author relies. Issues of ways of interpreting the rules of law are given attention in the works of such legal scholars as S. Alekseev, Y. Bytyak, O. Belyaeva, E. Vaskovsky, Y. Vlasov, M. Voplenko, O. Kaplina, V. Karaban, M. Kelman, M. Korkunov, O. Kostenko, V. Lazarev, P. Lublinsky, P. Lyutikov, L. Matveeva, J. Melnyk-Tomenko, D. Mikhailovich, J. Mikhailovsky, P. Nedbaylo, A. Pigolkin, S. Priyma, P. Rabinovych, I. Samsin, Y. Tkachenko, E. Trubetskoy, S. Fedyk, M. Tsvik, O. Cherdantsev, L. Chulinda, S. Shevchuk,

\section{G. Shershenevich and others.}

Formulation of the goals of the article (task statement) - on the basis of the analysis of various doctrinal sources to determine the methods and rules of contextual interpretation of concepts and categories of administrative proceedings.

Presentation of the main research material. We consider contextual interpretation in inseparable connection with philological interpretation, because the contextual way of interpretation is a kind of subspecies of philological interpretation, and its main method - contextual analysis - is an integral part of linguistic analysis. Its separate consideration within the framework of this study is mainly due to the presence within the CAS of Ukraine and other administrative-procedural legislation of a fairly large number of so-called evaluation concepts, the content of which is ambiguous.

«Context»-1) a complete passage of text, which allows to establish the meaning of a word or sentence that is part of it; 2) that it is considered as a whole, which connects and explains any phenomena, facts, etc. [1, p. 567]. In turn, the word "contextual» is an adjective to the word "context» and means - depends on the context associated with the context [1, p. 567; 2].

Instead, according to the Explanatory Dictionary of Translation, the «contextual meaning of the word»: 1 . Much depends on the nature of the semantic context, the semantics of the words associated with it. The 
contextual meaning of a word is always very effective both semantically and stylistically due to its surprise. It is often used for stylistic purposes and therefore the translator is faced with a double task: he must avoid leveling and at the same time not violate the rules of language translation. 2. Some meanings of words, absent in their semantic structure and obtained in the context due to special conditions of use, are transient, non-permanent, appear at the moment and are possible only in this context; is the most unstable, mobile, fluctuating in its content category, which is not realized in the context, but arises in it [3, p. 90-91].

According to the common understanding of these words, it is logical to assume that the so-called contextual interpretation involves determining in some cases necessary for the interpretation of a rule of law contexts of its understanding, in the use of which uses the method of contextual analysis.

Contextual analysis is a type of research in which, along with individual features of the phenomenon, the features of the contexts to which the phenomenon belongs are taken into account; contextual features act as independent variables that affect individual quantities or modify the relationship between individual quantities [4, p. 121].

As you know, the method of contextual analysis is quite common in the study of works of art. O. Chirkov notes that the contextual analysis of a work of art presupposes the existence of a certain context in which the work is studied and analyzed. According to the linguist, there are the following contexts: a certain historical and literary era (determining the place of the work in it); creativity of an individual writer (with the definition of the place of the work in it); of a certain historical period (the completeness of the reflection of the period in a literary work is studied) [5, p. 34].

In turn, the contextual interpretation of the law involves access to socio-cultural contexts (analysis of norms in the context of philosophical concepts, social values, etc.), law enforcement contexts (ie, case law), situational contexts (circumstances of the case). The meaning of interpretive expressions is considered not in their denotative, but in their connotative meaning. As we can see, contextual interpretation, like any other means of interpretation, uses logical techniques as well as rules of philological interpretation to establish the exact meaning of a concept or category. However, there are still subtle facets that distinguish this method of interpretation from a more general, generic for him - philological.

For example, philological interpretation uses philological-linguistic techniques and rules to determine the meaning of words and expressions, and if they were insufficient to achieve the result, the interpreter may, if appropriate, resort to a contextual interpretation in which it is primarily on identifying the meaning of the concept in the context of a particular dispute or the facts of the case, which may significantly vary the meaning of the concept being interpreted.

Contextual analysis of the legal norms of the CAP of Ukraine, containing concepts and categories, rarely resorts to the search for various possible socio-cultural contexts for the use of the concept being interpreted. As a rule, such contexts can be the subject of research when interpreting the relevant legal norms by the Constitutional Court of Ukraine, which is based on various philosophical concepts and socio-cultural contexts in determining the content of a legal provision. A clear example is the Court's legal interpretation of the rule of law set out in its individual judgments. For example, the CCU clarified that one of the manifestations of the rule of law is that law is not limited to legislation as one of its forms, but also includes other social regulators, including morals, traditions, customs, etc., which are legitimized by society and due to the historically achieved cultural level of society. All these elements of law are united by a quality that corresponds to the ideology of justice, the idea of law, which is largely reflected in the Constitution of Ukraine. Such an understanding of the law does not give grounds for its identification with the law, which can sometimes be unjust, including restricting the freedom and equality of the individual. Justice - one of the basic principles of law, is crucial in defining it as a regulator of social relations, one of the universal dimensions of law. Justice is usually considered as a property of law, expressed, in particular, in the equal legal scale of behavior and in the proportionality of legal responsibility for the offense [6].

- In other decisions, the CCU drew attention to other philosophical and value categories that underlie the principle of the rule of law, in particular such as efficiency, dimension, proportionality, etc .:

- "Based on a systematic analysis of the disputed provisions of the codes, the Constitutional Court of Ukraine concluded that they are based on the rule of law, in particular on such components as the effectiveness of the purpose and means of legal regulation, reasonableness and logic of law [7];

- "The Constitutional Court of Ukraine proceeds from the fact that observance of the constitutional principles of social and legal state, rule of law (Article 1, part one of Article 8 of the Basic Law of Ukraine) stipulates legislative regulation of public relations on the basis of justice and dimension decent living conditions for every citizen of Ukraine [8];

- "One of the elements of the rule of law is the principle of proportionality, which in the field of social protection means, in particular, that the measures provided for in regulations must be aimed at achieving a legitimate goal and must be commensurate with it» [9].

As for the Supreme Court, its practice also includes 
certain decisions in which the court, abstracting from excessively formalized approaches to resolving disputes by lower courts and criticizing them, tried to proceed from the context of the philosophical theory of anthropocentrism and its influence on law. Thus, setting out his understanding of the provisions of Art. 3 of the Constitution of Ukraine, the Grand Chamber of the Supreme Court noted that the constitutional norms on the recognition of man, his life and health, honor and dignity, inviolability and security as the highest social value, direction of content and direction of state rights, freedoms and guarantees, as well as the responsibility of the state for its activities to man and the definition of the main duty of the state, it follows that, in particular, establishing certain rules of conduct, the state must first take care of people's needs, refraining from establishing such rules that will be negatively perceived by certain groups in society. The establishment of such rules can be justified only by the presence of overriding public interests, which cannot be satisfied in any other way, but even in this case the principle of proportionality must be observed. [10].

When searching for law enforcement contexts and using them applied to interpreted concepts, the subject of interpretation relies on existing case law (usually the courts of higher instances). In this case, it is especially important to choose the most appropriate law enforcement act adopted in a similar dispute, in which the jurisdiction that "analyzes» the dispute, interpreted the concept and applied it to the type of public relations. Thus, during the law enforcement contextual interpretation the case law is used, the interpreted concept is investigated in the context of the formed approaches to its understanding, etc.

In turn, the situational context, the techniques of which help to determine the content of evaluative concepts, allows the subject of interpretation in part or in general to abstract from existing case law and take into account the specific circumstances of the case. Based on them, the court, using administrative discretion, can interpret the valuation concepts and its features that change in the context of these parties in the case, certain facts, legal and factual grounds of the dispute and so on. Naturally, the situational context is usually applied to each individual dispute.

An example of the use of contextual analysis is the Supreme Court's position. Thus, in its decision of 16.10.2018 in the case № 9901 / 637/18 on the recognition of illegal and cancellation of the decision of the High Qualifications Commission of Judges of Ukraine (hereinafter - VKKS) and the obligation to take certain actions, the decision noted that the decision of the body must be motivated. «The lack of motives in such a decision is a legally defined ground for its appeal and subsequent cancellation. This is directly enshrined in paragraph 4 of part 3 of Article 88 of the Law of Ukraine of June 2, 2016
«On the Judiciary and the Status of Judges». Taken together, these norms lead the Court to believe that the legislator requires the existence of motives as a mandatory component of the decisions made as a result of the qualification assessment and guarantees of observance of the rights of the person in respect of whom it is conducted. The Supreme Court pointed out that the impugned Decision contains only a list of means to establish a judge's suitability for the position (exam results, testing, dossier research, interviews), as well as the plaintiff's scores for each of the criteria, but no reasons for deciding on each of these criteria. and the arguments of the HCJC in favor of accepting or rejecting the arguments and evidence of the plaintiff and setting exactly that number of points [11].

Having made a contextual analysis of the word "motive», analyzing the bylaws, taking into account the specific circumstances of the case and the content of the contested decision of the Supreme Court, he concluded that the transparency of administrative procedures is an effective safeguard against state arbitrariness. A reasoned decision demonstrates to the person that it has been heard, gives the party the opportunity to appeal against it. Only if a reasoned decision is made can proper public and, in particular, judicial control over the administrative acts of the subject of power be ensured. ... The compliance of the members of the Commission with the specified procedure will be evidenced by the proper motivation of its conclusion: establishment of circumstances relevant for the correct resolution of each of the issues listed in Chapter II of Regulation № 143 / 3п-16 (items 1-10); reference to the evidence on which such circumstances are substantiated, indicating the reasons for their acceptance or rejection; assessment of the arguments and arguments of the person to whom the assessment procedure is applied; applicable and non-applicable rules of law, stating the reasons for their non-application. Conversely, failure to state the reasons for the decisions «subjectivizes» the act of a state body and does not allow the court to establish the valid grounds and reasons for which this body came to such conclusions, give them a legal assessment, and establish the legality, validity, proportionality of the decision. ... In addition, taking into account the above provisions of the Constitution of Ukraine and international recommendations, the decision on the results of the qualification assessment should contain a conclusion on which criterion (competence, professional ethics or integrity) the judge does not meet the position, because the judge is subject to dismissal. position only if he does not meet the position at least according to one of the above criteria: competence, professional ethics or integrity, and the inevitable conclusion from the evaluation process is that the judge is unable to administer justice at an "objectively defined minimum 
at an acceptable level.

Thus, the Commission's reference only to the means of establishing a judge's suitability for the position and the number of points awarded as a result of the qualification assessment do not allow to establish the specific criteria by which the plaintiff does not meet the position, in no way allows to establish Decisions and motives for its adoption. This applies equally to all parts of the contested decision, given that it is grounds for its cancellation as a whole» [11].

Conclusion. In view of the above, the contextual interpretation of the concepts and categories of administrative proceedings can be defined as a set of techniques and rules based on contextual analysis, which establishes the content of the concept or category of administrative process based on sociocultural, law enforcement and / or situational contexts. their significance.

Based on this, we formulate the basic rules and techniques of contextual interpretation of concepts and categories of administrative proceedings, in particular:

- reception of harmonious reading - the content of concepts or categories relating to one institution of the administrative process or the process as a whole should be interpreted in such a way as to make them compatible, and not contradictory;

- related words mean to each other;

- concepts are given the meaning that is associated with them in this circle of people;
- names and titles are valid indicators of the meaning of the relevant concept formulated in the CAS:

- if the legislative act does not define in one way or another the meaning of legal terms, they should be given the meaning in which they are used in acts of interpretation or in legal doctrine, etc. In particular, the CAS of Ukraine does not contain definitions of such concepts as: «in good faith», «prudently», the content of which is disclosed during law enforcement or in scientific and practical comments to the CAS of Ukraine or in scientific publications on these issues;

- application of situational contextual analysis techniques to the interpretation of evaluation concepts. Evaluative concepts, given their usually abstract nature, cannot be given unambiguous and complete meaning at the legislative level, so they have a variable meaning, which is determined by the jurisdictional entity depending on the nature of a public dispute. In such cases, the court applies wellknown techniques and methods of logical thinking (analysis, synthesis, induction, deduction, etc.) taking into account the specific circumstances of the case (situational context). In particular, in such concepts as "credible evidence», "sufficient evidence» the legislator gives only their key features with the further indication that, for example, the question of the sufficiency of evidence to establish the circumstances relevant to the case, the court decides in accordance with its inner conviction.

\section{REFERENCES:}

1. Busel, V. T. (2001). Velykyj tlumachnyj slovnyk suchasnoi' ukrai'ns'koi' movy [Large explanatory dictionary of the modern Ukrainian language]. Kyiv. (in Ukrainian).

2. Glossary of linguistic terms. URL: http://www.textologia.ru/slovari/lingvisticheskie- terminy/ kontekstualniy/?q=486\&n=726 (in Russian).

3. Nelyubin, L. L. (2003). Tolkovyj perevodovedcheskij slovar' [Explanatory translation dictionary]. Moscow. (in Russian)

4. Comprehensive explanatory sociological dictionary (2001). (in Russian).

5. Chirkov, O. S. (1997). Osnovy teorii' literatury. Chastyna persha [Fundamentals of literary theory. Part one]. Kyiv. (in Ukrainian).

6. Decision of the Constitutional Court of Ukraine in the case on the constitutional petition of the Supreme Court of Ukraine on compliance of the Constitution of Ukraine (constitutionality) with the provisions of Article 69 of the Criminal Code of Ukraine (case of sentencing by a court) of November 2, 2004 № 15-rp / 2004. (in Ukrainian).

7. Decision of the Constitutional Court of Ukraine in the case on the constitutional appeal of the limited liability company Prima- Service LTD on the official interpretation of paragraph 7 of part three of Article 129 of the Constitution of Ukraine and on the constitutional petition of 54 deputies of Ukraine on compliance with certain provisions of part six Article 12, part one of Article 41 of the Code of Administrative Procedure of Ukraine, part two of Article 197 of the Civil Procedure Code of Ukraine, as well as part eight of Article 81-1 of the Commercial Procedure Code of Ukraine (case of recording the trial by technical means) of December 8, 2011 № 16- rp / 2011. (in Ukrainian).

8. Decision of the Constitutional Court of Ukraine in the case on constitutional petitions of 49 people's deputies of Ukraine, 53 people's deputies of Ukraine and 56 people's deputies of Ukraine on compliance of the Constitution of Ukraine (constitutionality) with paragraph 4 of section VII «Final Provisions» of the Law of Ukraine «On State Budget of Ukraine 2011» Dated December 26, 2011 № 20-rp / 2011. (in Ukrainian).

9. Decision of the Constitutional Court of Ukraine in the case on the constitutional proposal of the Board of the Pension Fund of Ukraine on the official interpretation of the provisions of Article 1, parts one, two, three of Article 95, part two of Article 96, paragraphs 2, 3, 6 of Article 116, part two of Article 124, part one of Article 129 of the Constitution of Ukraine, paragraph 5 of part one of Article 4 of the Budget Code of Ukraine, paragraph 2 of part one of Article 9 of the Code of Administrative Procedure of Ukraine in systematic connection with certain provisions of the Constitution of Ukraine of January 25, 2012 № 3-rp / 2012. (in Ukrainian). 
10. The decision of the Supreme Court of September 19, 2018 in case № 806/3265/17 on the recognition of illegal inaction and the obligation to take certain actions. URL: https://verdictum.ligazakon.net/document/76822787.

11. Judgment of the Supreme Court of 16 October 2018 in case № 9901 / 637/18 on declaring illegal and revoking the decision and the obligation to take certain actions. URL: https://verdictum.ligazakon.net/document/77361545. (in Ukrainian). 